\title{
Research Paper \\ The Effect of Family Interaction Program Training on Couple Satisfaction and Communication Skills in Children with Autism Spectrum Disorder
}

\author{
Sedigheh Poormand ${ }^{1}$, Seyedeh Monavar Yazdi ${ }^{* 2}$, Sogand Ghasemzadeh ${ }^{3}$ \\ 1. M.A. Student of Psychology and Educational of Exceptional Children, Science and Research Branch, Islamic Azad University, \\ Tehran, Iran \\ 2. Professor, Department of Psychology, Faculty of Psychology and Educational Sciences, Alzahra University, Tehran, Iran \\ 3. Assistant Professor, Department of Psychology and Education of Exceptional Children, Faculty of Psychology and Educational \\ Sciences, University of Tehran, Iran
}

Citation: Poormand S, Yazdi SM, Ghasemzadeh S. The effect of family interaction program training on couple satisfaction and communication skills in children with autism spectrum disorder. Quarterly Journal of Child Mental Health. 2020; 6(4): 278-289

http://dx.doi.org/10.29252/jcmh.6.4.25

\section{A R T I C L E I N F O}

\section{Keywords:}

Autism disorder, communication skills, couple satisfaction, family interactions

Received: 4 Sep 2018 Accepted: 27 Dec 2018 Available: 10 Mar 2020

\section{A B S T R A C T}

Background and Purpose: Autism is a disorder associated with problems in social interaction, communication, and repetitive and limited behavior patterns. According to the results of some studies, some mothers of children with autism have higher levels of depression and stress symptoms than mothers of typically developing children, so the purpose of the present study was the effect of family interactions training on marital satisfaction and communication skills of children with autism spectrum disorder.

Method: The study was a quasi-experimental with pre-test, post-test, and control group design. The statistical population of the study included all mothers of children with autism spectrum disorder in Tehran in 2016. The study sample consisted of 24 mothers with autistic children from the mentioned population who were selected by convenience sampling method and randomly assigned to experimental and control groups (each group consisting of 12 persons). The intervention program was taught to the experimental group for 12 sessions and the control group did not receive this training. At the end both groups were evaluated in post-test and follow-up. The research tool was Gilliam Autism Rating Scale (1994) and Marital Satisfaction Questionnaire (Afroz, 2012) which were completed in three stages. The obtained data were also analyzed using covariance analysis

Results: The results of the data analysis showed that the intervention program increased the mean subscales of marital satisfaction, family interactions, and communication skills of autistic children in the experimental group $(\mathrm{P}<0.05)$, while the post-test scores of the control group in all subscales did not change significantly.

Conclusion: Based on the findings of the present study, it can be concluded that the family interactions training used in this study was able to improve the communication skills of children with autism by increasing the level of parental awareness and improving the appropriate interaction with the child and spouse.

\footnotetext{
* Corresponding author: Seyedeh Monavar Yazdi, Professor, Department of Psychology, Faculty of Psychology and Educational Sciences, Alzahra University, Tehran, Iran.

E-mail addresses: Smyazdi@alzahra.ac.ir
} 


\title{
تأثير آموزش برنامه تعاملات درونخانوادكى مادران بر رضامندى زوجيت و مهارتهاى ارتباطى كودكان مبتلا به اختلال طيف اوتيسم
}

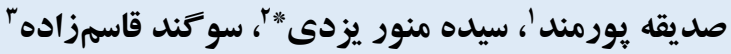

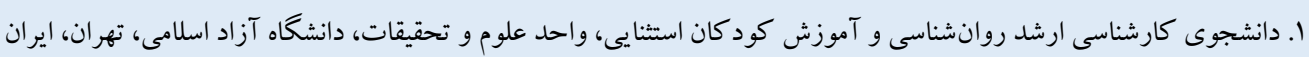

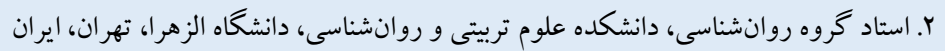

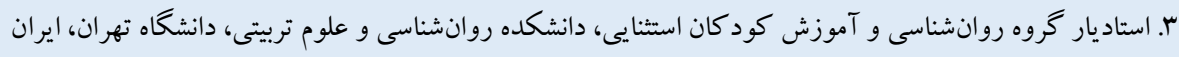

زمينه و هدف: اوتيسم اختلالى است كه با مشكلاتى در تعامل اجتماعى، برقرارى ارتباط، و الكوهاى رفتار تكرارى و محدود همر اه است.

مشخصات مقاله

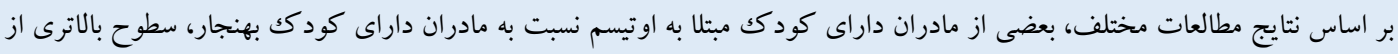

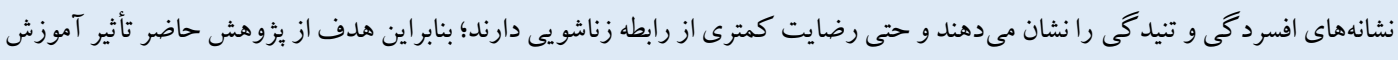

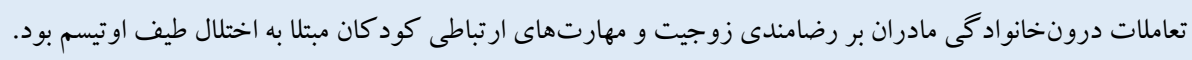

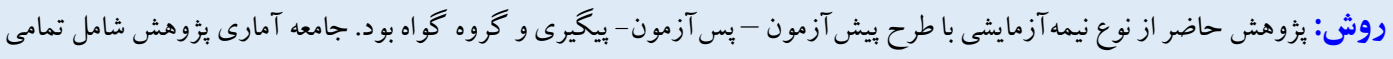

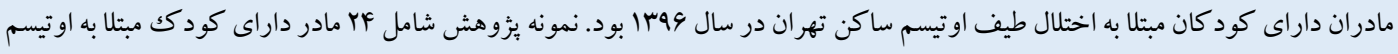

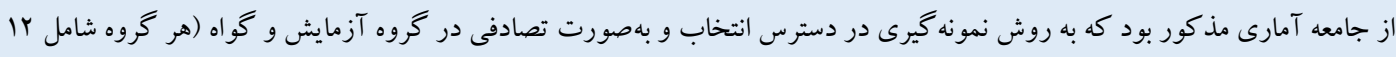

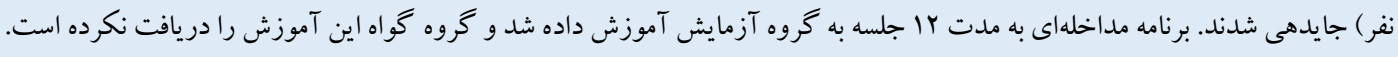

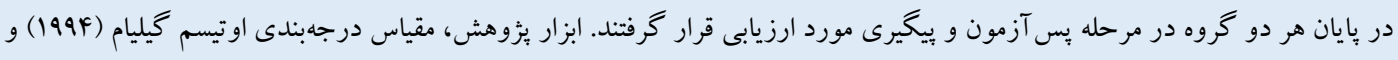

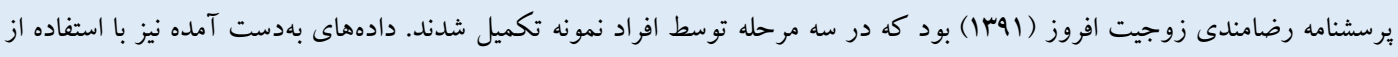
تحليل كوواريانس مورد بررسى قرار كرفتند.

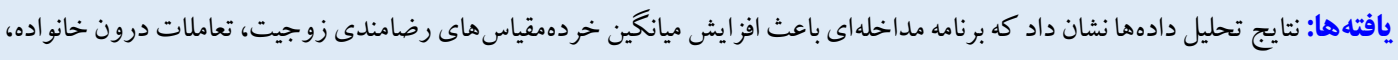

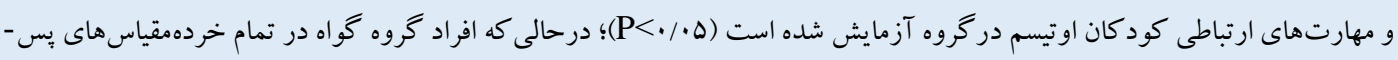
آزمون، تغيير قابل توجهى نداشتند.

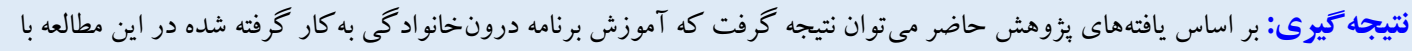
دريافت شده: 9V/.9/1T

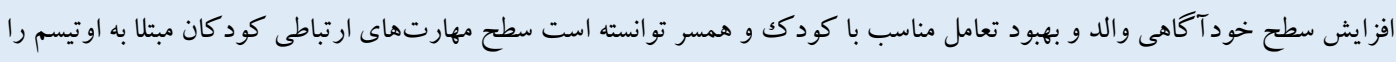

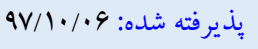

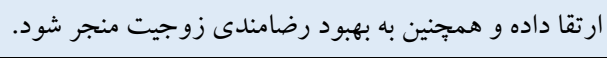
منتشر شده: • • 
ارشـاد سـر ابى، هاشـمى رزينى، و عبداللهى (9) در يزٔوهشىى عنوان كردند وجود كودكك با نيازهاى ويزه اغلب آسيب هاى جبراننايذيرى را بر خـانواده تحميـل مى كند. ميزان اين آســيب، كاه به حدى اســت كه

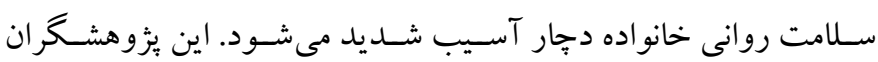
همجينين در مقايسه تنيدگى والدگرى، سبك هاى والدگرى، و حل مسئله اجتماعى مادران مبتلا به اختلال طيف اوتيسم، نارسايى توجه/فزون كنشى، و بهنجار نتيجه گرفتند كه تنيدگى والدگرى در دو گرووه طيف اوتيسم و نارسـايى توجه متفاوت است. همجنين هر جند هر دو گروه تنيدگى نسبتاً زيادى را تحمل مى كنند، اما اين تنيدگى به عو امل متعددى بستخى دارد و براى مـديريت ســطح اين تنيدگى عو املى مانند تشــخيص زودهنگگام اين گونه اختلال ها، روحيه همكارى، دسـترسى به سيستم مر اقبتى مؤثر، و استفاده از خدمات مؤسسات داراى اين كود كان توسط والدين را بيشنهاد كردند. در بززوهشى ديكر ( •1) اعنوان مشكلات خانو ادههاى كود كان با اختلال طيف اوتيسم نتيجه كرفته شد كه والدگرى براى هر دو والد بدر و مـادر تنشزاســت، امـا مادران بيش از بدران تنش والدكرى را تجربه مى كنـــ. در نتيجـهـ اختلـال طيف اوتيســـم از يِيجيدهترين اختلال تحولى اسـت كه كنار آمدن با آن براى خانو ادهها بسـيار دشـوار اسـت. از ديكر

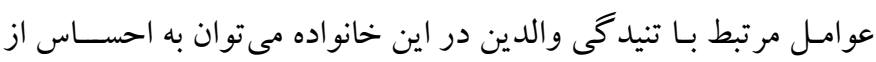
دست دادن مهاركرى شـخصى، فقدان حمايت همسر، و فقدان حمايت تخصـصى اشاره كرد ( ·1). حسين خانزاده، باغبان وحيدى، و ندايى (11) در يُزوهشى تحت عنو ان تأثير آموزش مهارت هاى برقرارى ارتباط مؤثر به مادران كود كان داراى اوتيسـم بر جو عاطفى سـازش يذيرى و انسـام خانواده بيان كردند كه اوتيســم بر يويايىهاى خانواده تأثير جدى دارد، بهطورى كه سـبب فشـار مضـاعف بر مراقبان بهويثزه مادران مى شود. اين فشـار يكى از معظلات اصـلى اعضــاى خانو اده بهويزٔه مادر بهحسـاب مى آيد و افر اد خانو اده اين كود كان به علت زمانى كه صــرف مراقبت و درمان از كودك مى كنند، تعامل و فعاليتهاى اجتماعى محدودى دارند كه اين موضـوع باعث ايجاد فاصله بين همسران و در نتيجه تأثير منفى بر روابط بينفردى و زناشويى آنها مى شود. وجود كود كك او تيســم داراى عوارض جانبى نيز بر ســازش يافتخى زناشــويى و فعاليتهاى روزمره خانو اده به همر اه دارد. اعضــاى خانواده مقلdo

او تيسـم' يكك اختلال عصسبى تحولى اسـت كه با مشـكلات در رفتارهاى اجتماعى و رفتارهاى تكرارى همراه است ( (1). در طول سى سال كذشته، اختلالهاى شـناختى يايدار در اوتيسـم، بهطور فزاينده مورد بررسسى قرار كرفته اســت (Y). در حال حاضــر اختلالهاى طيف اوتيســم بر اســاس راهنماى تشــخيصـى و آمارى اختلالهاى روانى انجمن روانيزشــكى آمريكا بهعنوان يكك اختلال واحد تعريف مىشــود، يعنى اختلال هايى را در برمى گيرد كه قبلاً بهصـورت جداكانه در نظر گرفته مىشــدند (r). همجيخنين شـيوع اختلال طيف او تيســـم به دلايل مختلفى در حال افزايش اسـت. در گزارش ارائه شده توسط مركز كنترل بيشخيرى و بيمارىهاى آمريكا، از هر هو كودكك يكك نفر به اختلال طيف اوتيسـم مبتلا اسـت و شـيوع اين اختلال در يسـران Fٔ برابر بيشـتر از دختران است (F). در مورد تعداد كود كان اوتيســم در ايران، هيج گونه اطلاعات دقيقى در دسـترس

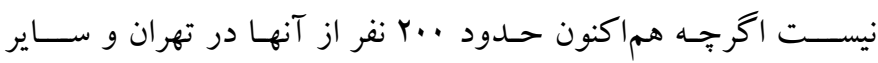
شهرستانها تحت بوشش آموزش مداخله رفتارى قرار دارند. در بثوهشى كه روى كود كان ^ ساله انجام شده است، مشخص شد كه بهطور كلى از

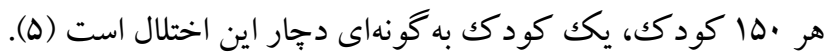
بايد توجه داشت كه همه والدين در تطبيق دادن شيوههاى والدگرى خود با نيازهاى فرزندانشان با مشكلاتى مواجه هستند، اما بدر و مادرهايى كه فرزند مبتلابه اختلال طيف اوتيسم دارند با مشكلات بزرگكترى درگير هستـند كه با مشكلات برورش كود كان بهنجار قابل مقايسه نيست. تعامل با كودكى كه از نظر ذهنى ناتوان يا كمتوان است تنيدگى روانى خاصى را بر والدين بهويزه مادران و كل خانو اده تحميل مى كنند كه به دنبال آن مشكلات و مسائل بسيارى را به وجود مى آورد (4). والدين كود كان مبتلا به اوتيسـم شـبيه به كسـانى هستند كه بهطور مشخص با كشاكشى مواجه شــند كه با تنش همراه اسـت و نسـبت به والدينى كه كود كان بهنجار دارند از تنش و تنيدكى بيشــترى برخوردار هســتند (V). بيمارى بايدار كودك، اضــطراب در مورد آينده او، انزواى اجتماعى، به تعويق افتادن تشـخيص، دشـوارى مواجه با تشــخيص و نشـانه هاى همر اه، دسـترسىى ضعيف به خدمات بهداشتى و حمايت اجتماعى سبب مى شود كه مادران اين كود كان سطح بالايى از تنيدگى را تجربه كنند (A). 
خانو اده و شــيوههاى والدكرى والدين را بر رشــد مهارت هاى اجتماعى

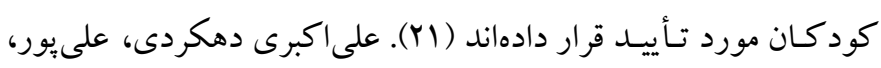

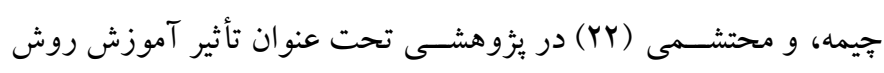
درمانى بِاسـخ محور به مادران كود كان مبتلا به اختلال او تيسـم بر عملكرد

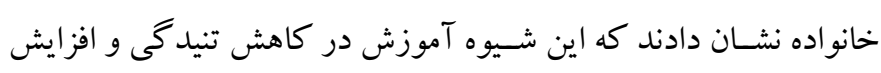
خود كـار آمـدى و كاركرد خانواده دار اي كود كك مبتلا به اوتيســم كاملاً مؤثر اسـت. همجينين تفرشسى و همكاران (سץ) به .ب نفر از مادران روش تحليل رفتار كاربردى را آموزش دادند تا آنها از اين روش براى افزايش مهارت هاى خوديارى كودكك خود استفاده كنند. نتايج مطالعه آنها نشان داد كـه اعتمـاد بـه خود، مهـارت خوديـارى، رفتـار اجتمـاعى مثبـت، و مهارت هاى روزمره زندكى در كود كان مبتلا به اوتيسم افزايش يافته است و همجينين تنيدگى و افسردگى والدين اين كود كان كاهش يافت. بايد توجه داشــت كه كود كان طيف او تيســـم با مشــكلات رفتارى إن متعددى مواجه هسـتند. اين كود كان نسـبت به همسـالان بهنجار بيشتر در معرض خطر مشـكلات هيجانى و اجتماعى هسـتند (YF) كه روى والدين آنها تأثير منفى به جا مى گذارد. شـكرى، خانجانى و هاشــمى (Yه) در

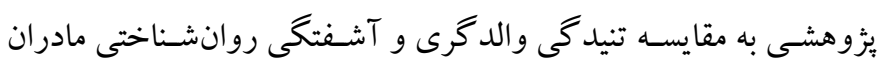
كودكـان مبتلـا بـه اختلال طيف اوتيســم و تأخير تحولى برداختند. نتايج نشان داد كه والدين كود كان اوتيسم روزانه با جالشهاى بالقوه و عو امل تنش آور متعددى از جمله مشـكلات رفتارى كودكك، مهارت ارتباطى، و تعـاملـات اجتماعى ويايين كودكك روبرو هســتند. آســيب در رفتارهاى اجتماعى شـــن در كود كان اوتيســم نســبت به كود كان مبتلا به ســاير اختلالهاى تأخير تحولى با شـدت بيشـترى وجود دارد. مادران كود كان او تيسـم بهطور يايدار سـوح تنش بيشترى را نسبت به مادران كود كان با ديخر تأخيرهاى تحولى و كود كان بهنجار دارا هستند؛ بنابر اين ضـرورى اسـت كه برنامه ها و خدماتى براى خانو ادهها و سـريرسـتان اين كود كان

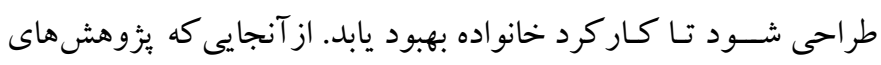
اندكى در زمينه تعاملات درونخانوادگى مادران بر رضـامندى زوجيت و مهارت هاى ارتباطى كودكك مبتلا به اختلال طيف اوتيسـم به خصوص در بـافت فرهنكى ايران انجام شـــده اســت و با تو جه به اين كه اين اختلال كودك بر شاخص هاى سلامت روان والدين و رضايت والدين از زندكى مشـتر كى تأثير كذار اسـت؛ بنابراين مسئله اصلى بثروهش حاضر اين است

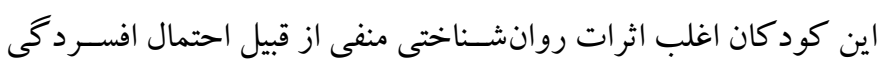

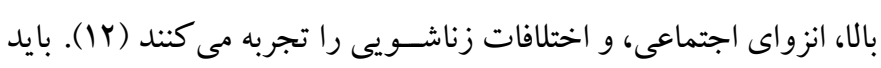

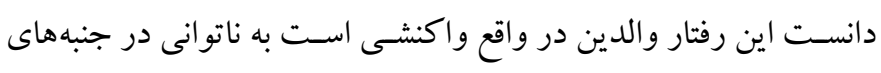

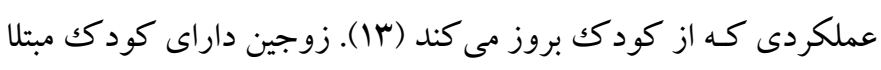

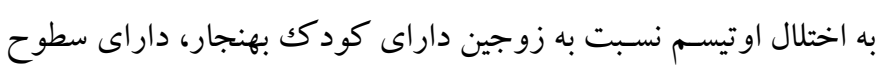

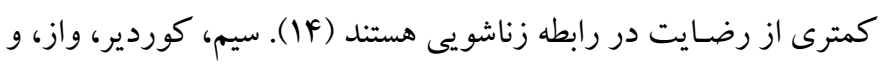

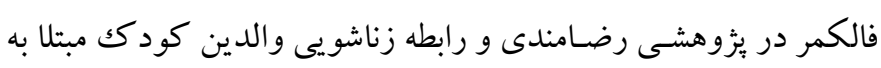

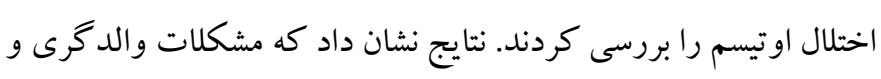

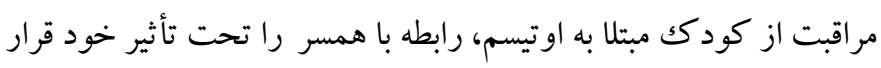

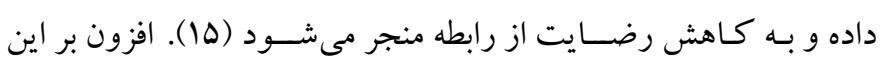

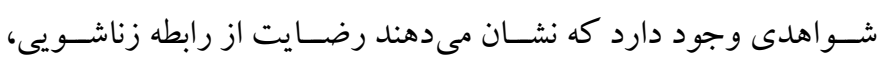

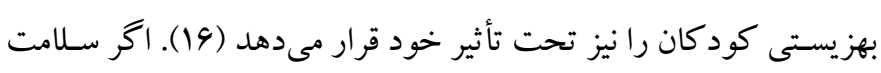

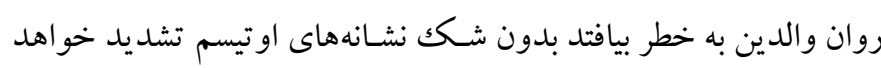

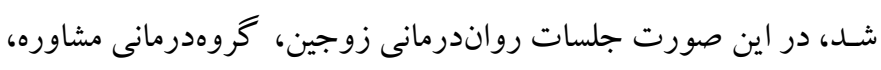

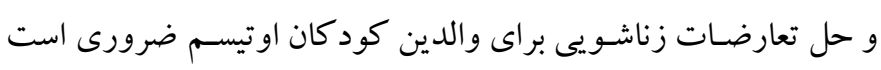

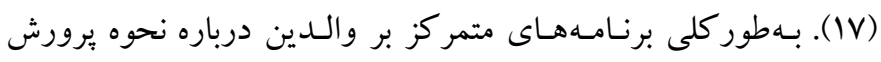

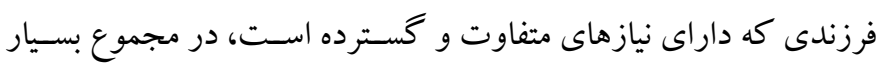

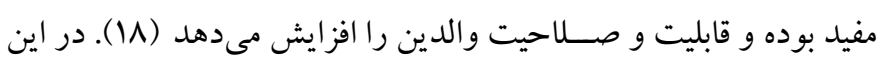

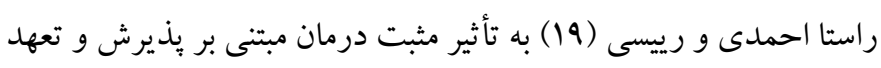

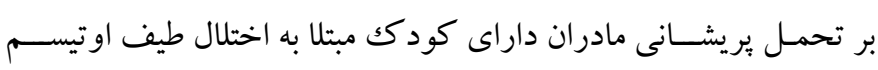

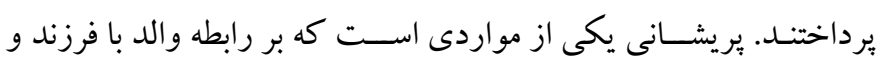

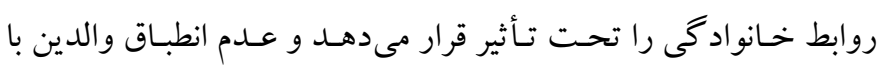

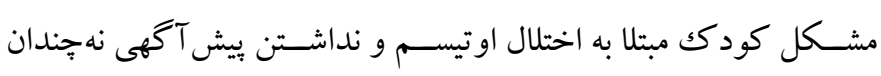

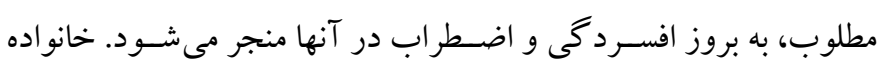

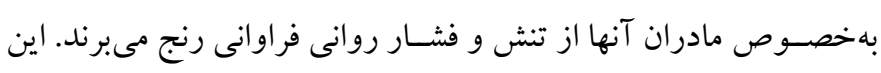

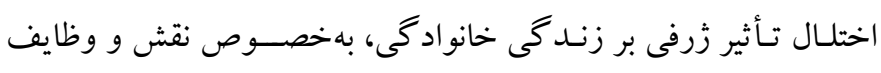

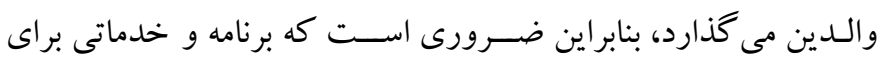

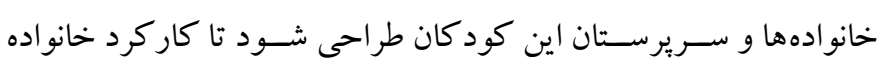

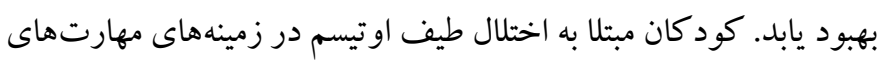

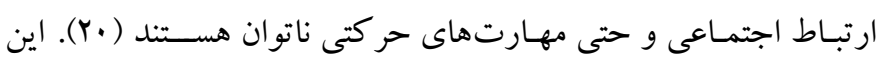

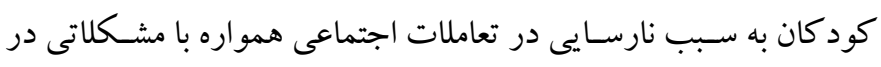

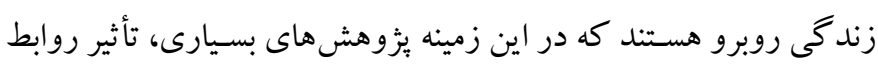


براى مقايسـه مهارت هاى ارتباطى كود دك او تيسـم قبل و بعد از جلسـات

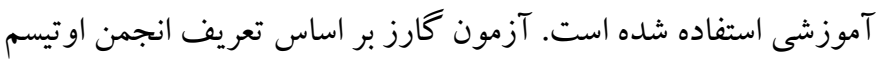

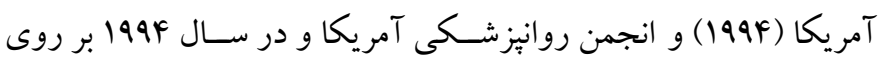

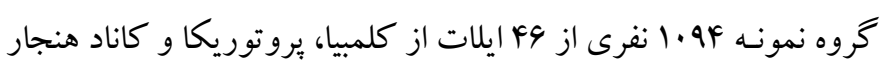

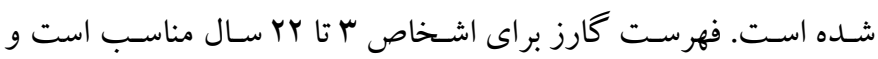
مى تواند توسـط معلم يا والدين در خانه يا مدرسـه كامل شـود. اين ابزار

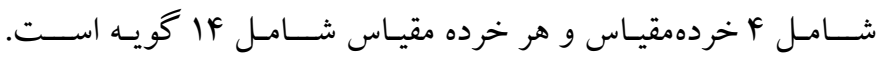

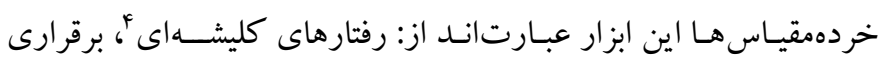

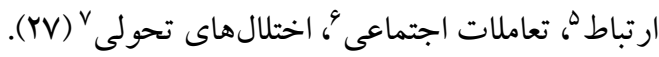

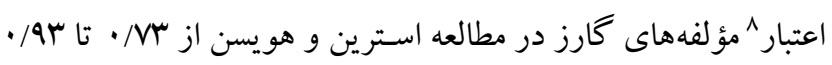

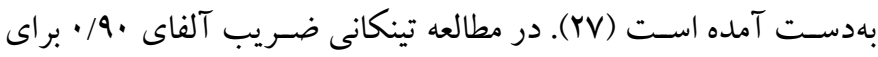

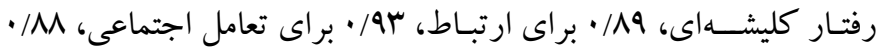

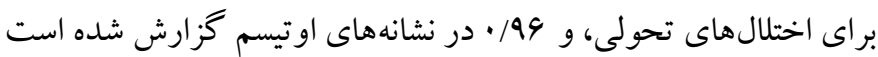
(YN)

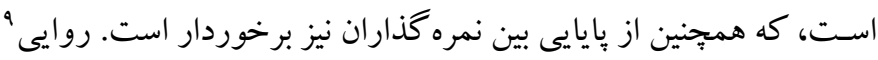

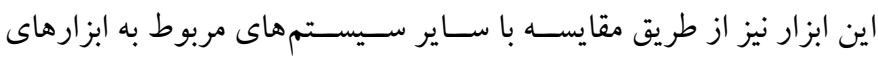

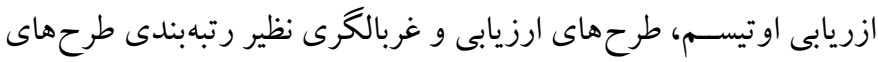

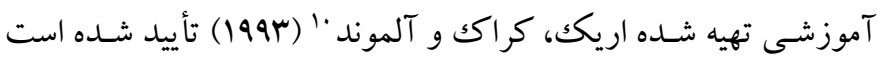

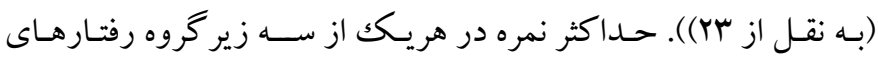

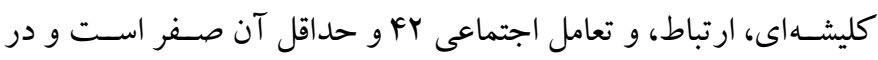

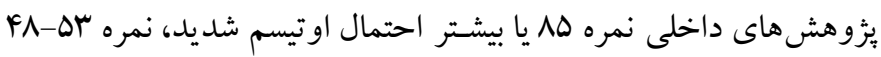

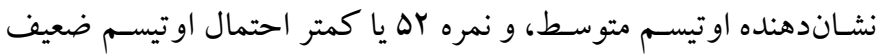

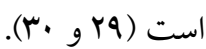

Y.r مقياس رضايتمنلدى زوجيت: مقياس رضـايتمندى افروز بر اسـاس

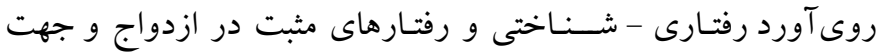

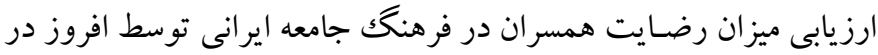

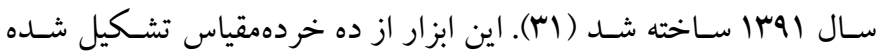

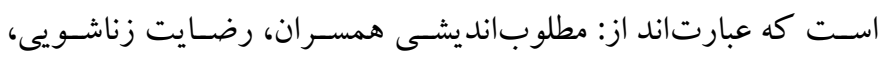
افكارهاى شـخصى، افكارهاى ارتباطى و اجتماعى، روش حل مسـئله،

6. Social interaction

7. Developmental

8. Reliability

9. Validity

10. Aric, Krug, Almond
كه آيا آموزش تعاملات درونخانو ادگى مادران بر رضـامندى زوجيت و مهارتهاى ارتباطى كود كك تأثير دارد؟

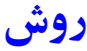

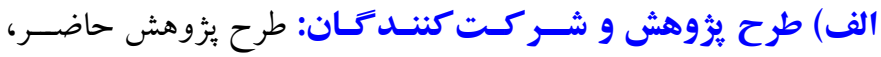

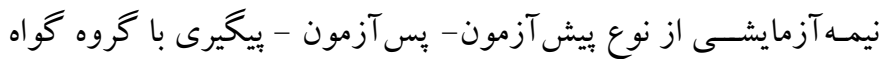

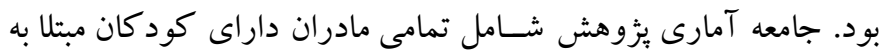

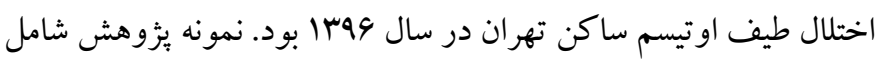

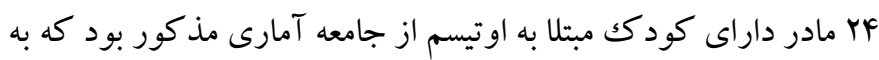
روش نمونه گيرى در دسـترس انتخاب و بهصـورت تصــادفى در گرووه

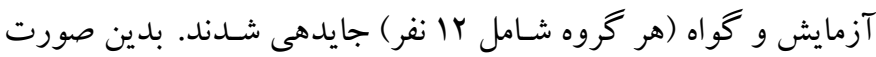

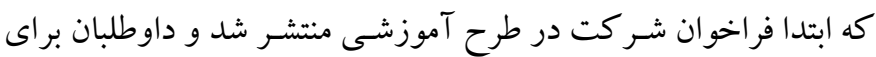

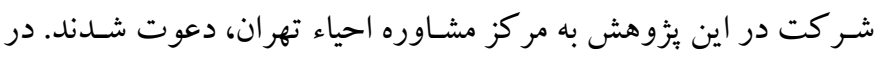

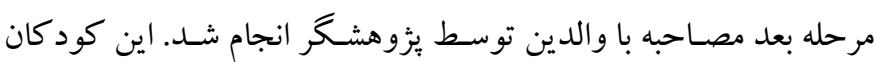

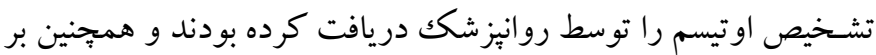

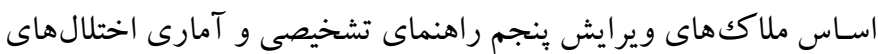

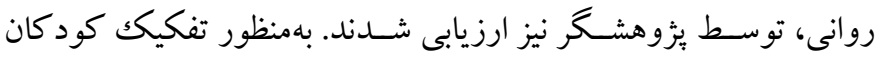

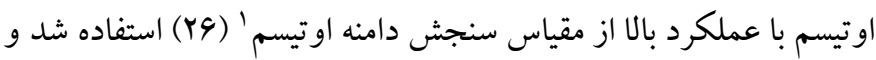
كود كانى كه نمره كلى آنها Y بود بهصورت نمونه به بهون مورد مطالعه انتخاب شدند. ملاككهاى ورود به يزوهش عبارت بود از: تشخيص اختلال اوتيسم

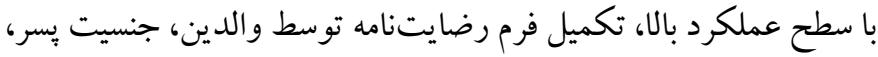

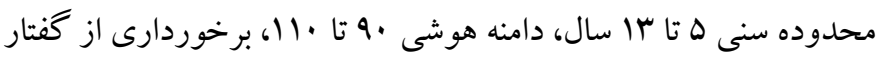

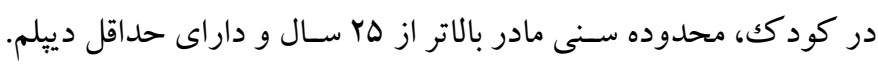
ملاككهاى خروج از يزوهش عبارت بود از: دارا بودن اختلال همر اه (مانند

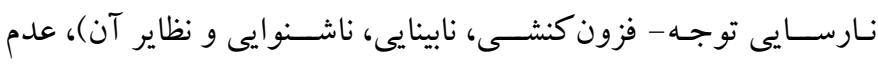
همكارى مادر در هنگام مداخله و انجام تمرينات.

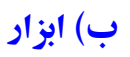

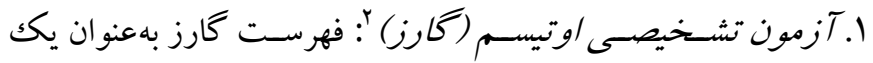

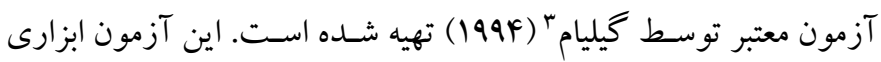

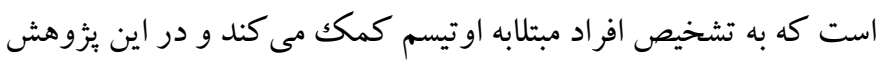

1. The high-functioning autism spectrum screening questionnaire 2. Autism Rating Scale (GARS)

3. Gilliam

4. Stereotyped behaviors

5. Communication 
نظريهيردازان شـناختى رفتارى مانند بكك (199V) و اليس r (199Y) معتقد

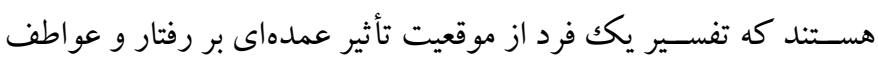
بعدى او خواهد داشت (Yr). مهارت هايى مانند مهار تنيدگى، مهار خشم و ... به مادران داراى كود كان اوتيسم در طى با جلسه آموزش داده شد. براى مشـاركت دادن هرجّه بيشـتر شـركت كنند كان در فرايند آموزش از

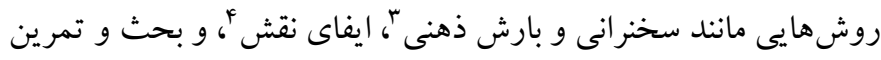

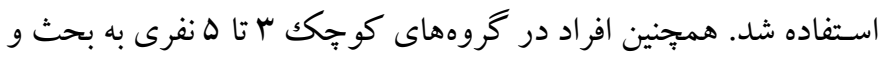
تبـادل نظر دربـاره آموخته هايشــان و انجام فعاليتهاي گروهي در زمينه موضــوع مربوطـه مى يرداختنـــ و تمرينهـاى ارائه شـــده در جزوههاى آموزشى را انجام مىدادند. خلاصه محتواى آموزشى برنامه مداخلهاى در

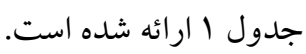

امور مـالى و فعـاليتهاى اقتصــادى، احســاس و رفتارمذهبى، روش والدگرى، اوقات فراغت، و تعامل احسـاسى. نمره بالاتر در اين آزمون، نشاندهنده رضامندى زوجيت بالاتر است. در اين ابزار زوجين به هر يكك از ســؤالات بر اســاس طيف ليكرت جهار گزينهاى (كاملاً مخالف الف مخالف Y، موافق ب، و كاملاً موافق F) يُاسخ مىدهند. روايى محتوايى اين آزمون با نظرسـنجى از هشـت متخصـص روانشـناس و مشاور ازدواج و خانو اده مورد بررسى و مطالعه و تأييد قرار گرفت. ضريب آلفاى كرانباخ نمره كل مقياس ه 1 • و همبستگى نمرات همسران در اين آزمون با نمره آنها در يرسشنامه "رضامندى زناشويى انريج " "بع/· به دست آمده است

ج) برنـامــه مــاخلـهاى: برنـامـه مداخلهاى تعاملات درونخانوادكى

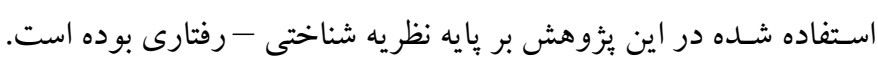

جدول ا: هدفها و محتواى جلسات آموزشى

\begin{tabular}{|c|c|c|}
\hline محتوا & 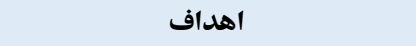 & 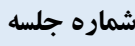 \\
\hline تعامل و رابطه در خانو اده، شناخت اختلال اوتيسم، تأثير اين اختلال بر نظام خانواده و تعاملات درون خانواده & ت تعامل & 1 \\
\hline توضيح در مورد تنيدگى، عو امل مؤثر بر تنيدگى و شيوه مهار تنيدگى & مهار تنيدگى & r \\
\hline تنيدگى در زندگى زناشويى و راههاى حل تنيدگى در زندگى والدين و خانو ادههاى داراى كود كك اوتيسم & مهار تنيدگى & r \\
\hline توضيح و توصيف خشم، نمونههايى از اختلافات زناشويى و موقعيت خشمبر انخيز، ارائه راهل & 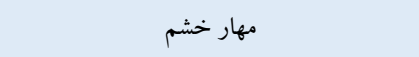 & f \\
\hline توصيف موقعيتهاى خشمبرانگيز براى خانواده و كود كك مبتلا به اوتيسم، علل خشم و عصبانيت در زندگى زناشويى والدين كودكى & 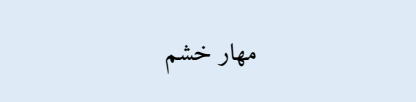 & $\Delta$ \\
\hline تعريف ارتباط، سلسلهمر اتب نيازهاى انسان، تعريف ارتباطات در اختلال اوتيسم و ارائه راهحل هايى براى بهبود ارتباطات اجتماعى & ارتباط مؤثر & 4 \\
\hline 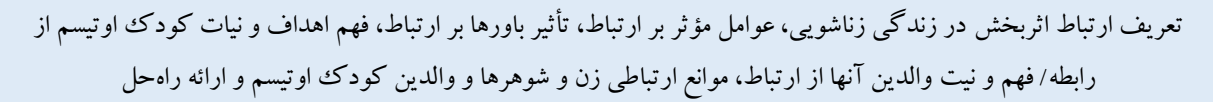 & ارتباط مؤثر در زندگى و بهبود رضايت از زندى & $v$ \\
\hline معناى خود آكاهى و اهميت آن در زندگىى، خودشناسى و توضيح نظريه ذهن در كودكى داراى اختلال & خودشناسى و خود آكاهى & $\wedge$ \\
\hline قدرت فكر، قدرت انتخاب، برنامهريزى براى زندگى زناشويى بهتر و بهبود روابط والدين كود كك اوتيسم، مهارتهاى دلخرم كردن و & خودشناسى و ارتباط آن در بهبود رضايت از زندى & 9 \\
\hline اهميت تصميم گيرى و حل مسئله در زندگى و در ارتباط با كودكى، تصميم گيرى والدين درباره مسائلى ييرامون كودك اوتيسم & تصميم گيرى و قدرت انتخاب و حل مسئله & 1. \\
\hline مساوات در زندگى زناشويى، استفاده از مهارتهايى در هنگام بحث و تبادلنظر و قرارداد زناشويى، مساوات در نخهدارى و رسيدگى بـ اوتيسم & 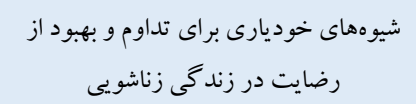 & 11 \\
\hline 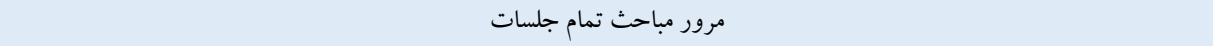 & بازسازى تعميم آموختها & ir \\
\hline
\end{tabular}

شـد با روش نمونه گيرى در دسـترس انتخاب شـدند. ابتدا يرسـشنامههاى يثزوهش در مرحلـه ييش آزمون بر روى شــركت كنــد كان هر دو كروه

3. Brainstorm

4. Role playing
د) روش اجرا: در اين ثئوهش يس از اخــذ مجوزهـاى لـازم علمى و اجر ايى، افراد نمونه به شـرحى كه در بخش روش شـناسى اين مقاله كفته

1. Evaluating \& nurturing relationship issues

2. Ellis 


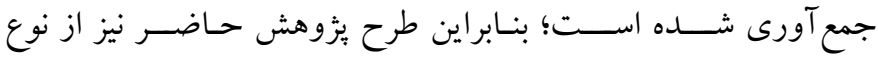

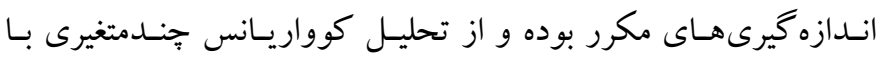
اندازه خيرىهاى مكرر براى تحليل دادهها استفاده شده است.

\section{يافتهها}

شايان ذكر است قبل از انجام اين تحليل ابتدا مقادير يرت بهوسيله نمودار

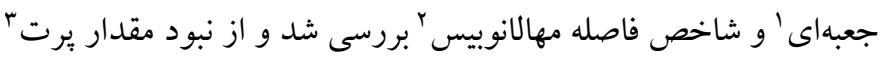

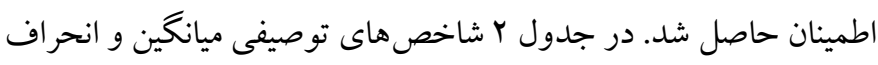

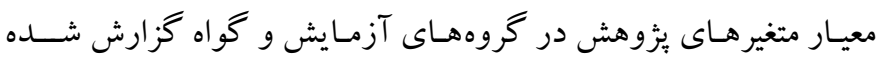

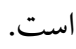

آزمايش و گگ اه اجرا شـد. سبس متغير مستقل (تعاملات درونخانوادگى)

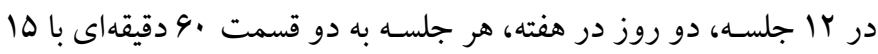
دقيقه استراحت و يذيرايى بين دو ساعت و با حضور والد مادر اعمال شد.

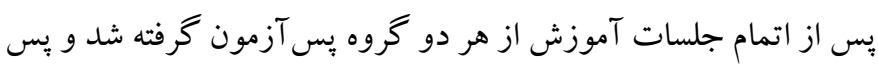

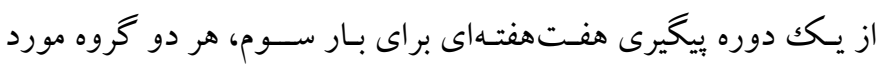

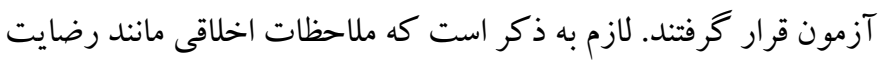
كتبى افر اد نمونه و اطمينان آنها از محر مانه ماندن دادههاى به دست آمدره و ... به طور كامل در اين مطالعه رعايت شده است.

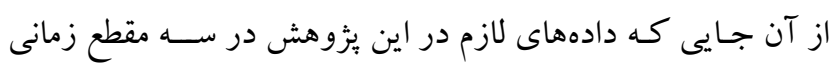

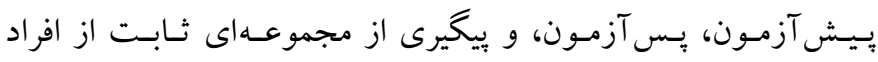

جدول r: شاخصهاى توصيفى متغير هاى رضامندى زوجيت و مهارت ارتباطى

\begin{tabular}{|c|c|c|c|c|c|}
\hline \multicolumn{2}{|c|}{ كروه كواه } & \multicolumn{2}{|c|}{ كروه آزمايش* } & \multirow{2}{*}{ مرحله } & \multirow{2}{*}{ متغير } \\
\hline انحراف معيار & ميانكين & انحر اف معيار & ميانغين & & \\
\hline $1 r / 99$ & rVQ/AY & $\mid r / \cdot 1$ & rVV/IV & بيش آزمون & \\
\hline $11 / 91$ & rVN/·A & $1 Y / 9$. & $M F Y / \cdot \Lambda$ & يس آزمون & رضامندى زوجيت \\
\hline- & - & $11 / 99$ & $M F I / 9 V$ & ييخيرى & \\
\hline$\Delta / \Delta 1$ & $\Delta \cdot / \Lambda r$ & $\Delta / r I$ & $\Delta \cdot / V \Delta$ & يُش آزمون & \\
\hline$\Delta / 9 V$ & $\Delta \cdot / V \Delta$ & $\Delta / r \mid$ & rI/qr & يس آزمون & مهارت ارتباطى \\
\hline - & - & $\Delta / Y F$ & $r q / \wedge r$ & يِيخيرى & \\
\hline
\end{tabular}

بيش آزمون تا بيگيرى از تحليل واريانس با اندازه گيرىهاى مكرر استفاده

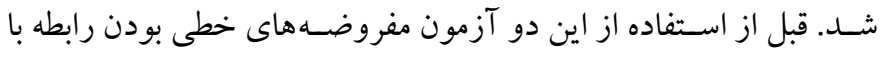

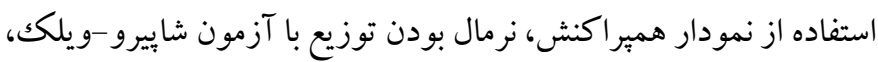

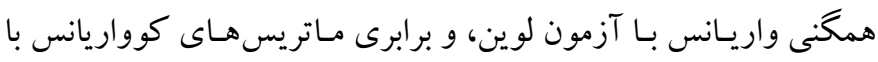

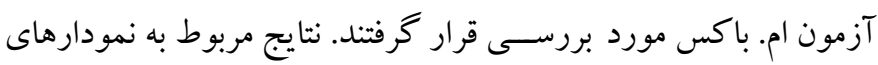

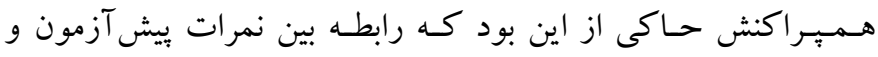

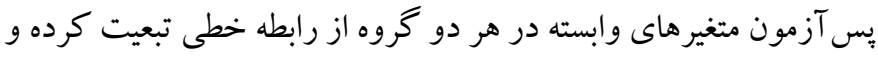

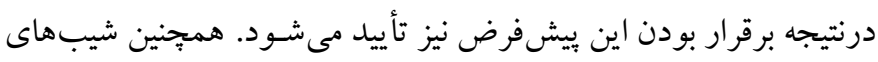

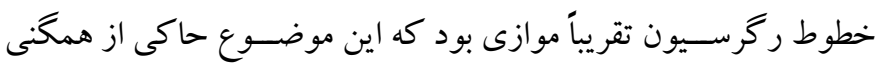

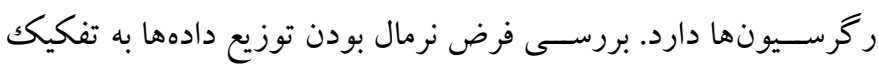

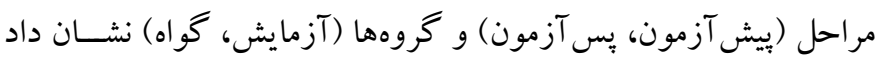

\section{Outlier}

جدول r نشـانگر افزايش ميانگين در متغير رضـامندى زوجيت گروه آزمـايش، يس از دورة آموزش (مرحلـهُ يس آزمون و يِيخيرى) اســـت. همجنين ميـانكين متغير مهارت ارتبـاطى گروه آزمـايش، بـ از از دورة آموزش (مرحلة يس آزمون و ييخيرى) كاهش يافته است؛ بهعبارتديخر

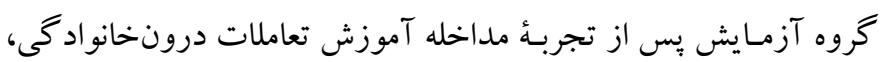
شـر ايط بهترى راكزارش كرده اسـت. اين در حالى است كه كروه گواه تقريبـاً در تمـامى متغيرهـا در مراحل بيش آزمون و يس آزمون تغيير قابل ملاحظهاى را نشـان نمى دهد. شـايان ذكر اسـت كاهش ميانگين در متغير مهارت ارتباطى به معناى تغيير مثبت در مورد اين متغير اســت. در ادامه جهـت مقـايســهـ كروههـاى بعـد از اعمـال مداخله از تحليل كوواريانس جندمتغيره و براى بررسـى اثر مداخله بر گروه آزمايش در طول مراحل

1. Boxplot

2. Mahalanobis distance 
نتايج جدول ب حاكى از آن اسـت كه ميانخين نمرات اصـلاح شـــه

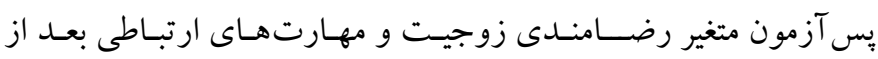

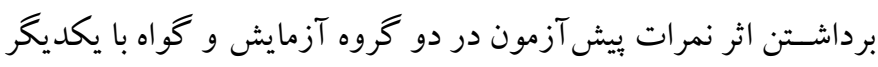

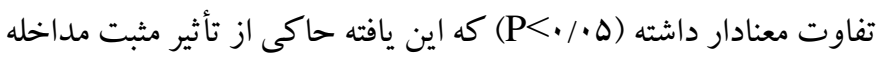

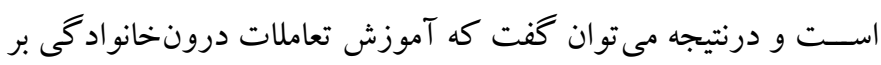
رضامندى زوجيت مادران و مهارت هاى ارتباطى فرزندان اثر خذار است.

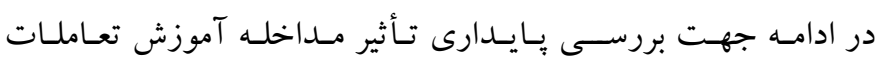

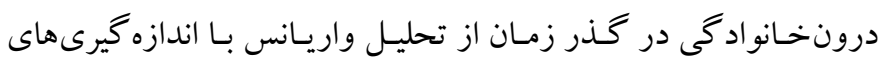

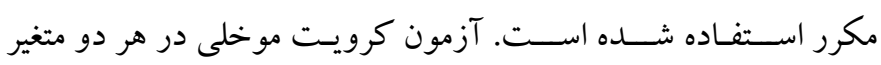
رضـامندى زوجيت (Mauchly's W=•/11) و مهارت هاى ارتباطى موردي (Mauchly's W=•/r/ه)

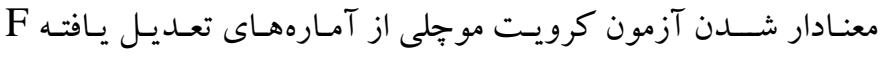

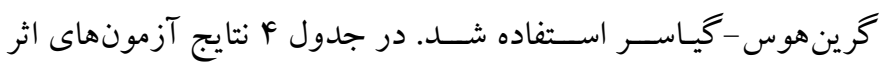
درون گروهى (اندازه گيرى مكرر) گزارش شده است.

\section{جدول §: نتايج آزمونهاى اثر درون كروهى (اندازهَيرى مكرر)}

\begin{tabular}{|c|c|c|c|c|}
\hline معنادارى & $\mathbf{F}$ & دآزادى & نوجذورات & متغير \\
\hline.. .1 & YYN/IY & $1 / \cdots 0$ & 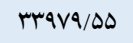 & رضامندى زوجيت \\
\hline.$/ .1$ & $\Delta G / Y q$ & $1 / 1 \wedge$ & rY.ANY & مهارتهاى ارتباطى \\
\hline
\end{tabular}

نتايج جدول F حاكى از آن است كه F متغيرهاى رضامندى زوجيت

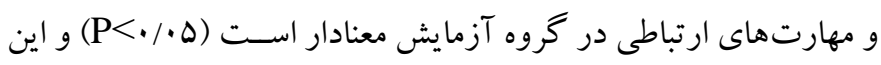

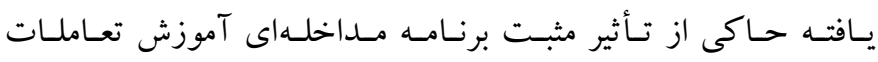

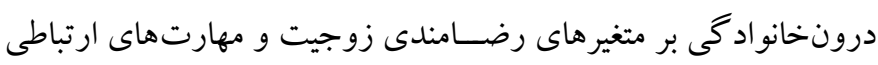

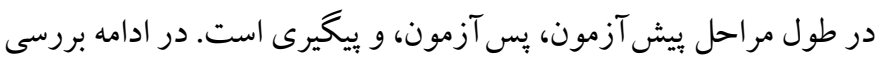

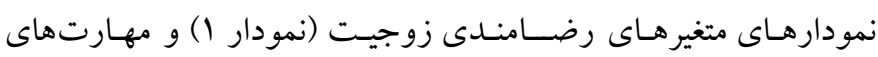

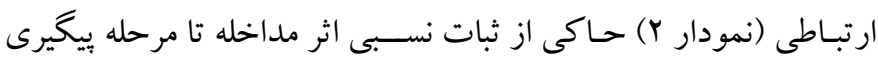

كـه در هيج يـك از متغيرهـا، آمـاره شـاييرو -ويلـك معنـادار نيسـتـ

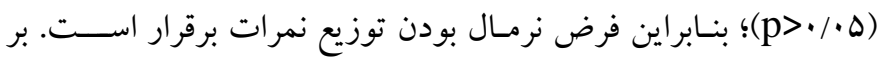

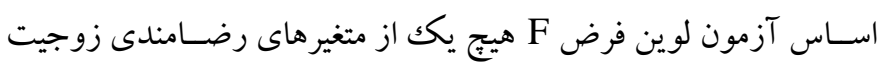

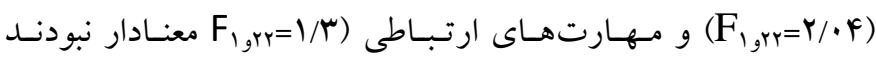

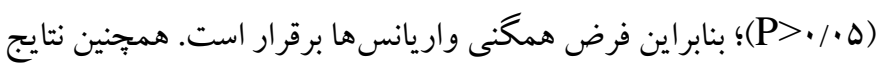
آزمون ام. باكس (Box’s M=•/V9 و Fr

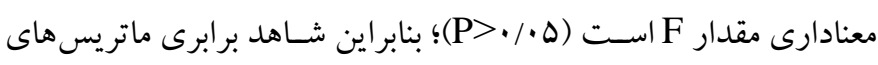

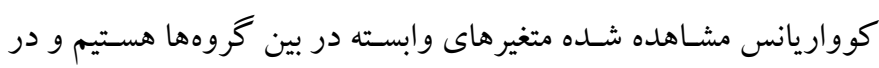

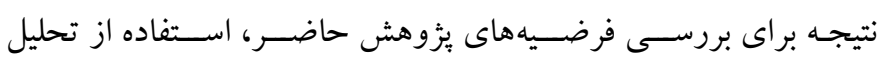

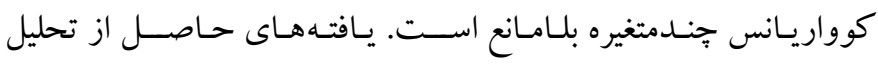

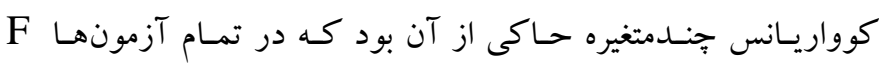

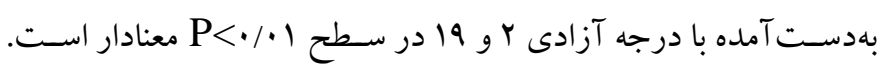

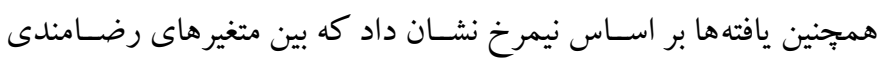

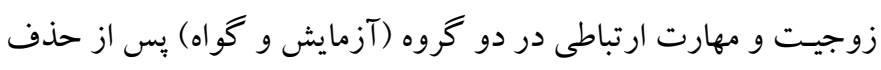
اثر ييش آزمون، تفاوت معنادار وجود دارد و r و F

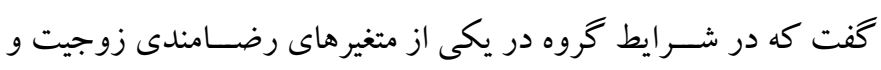

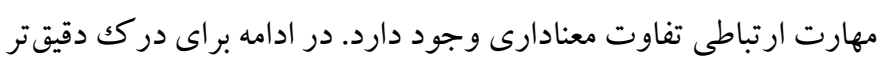

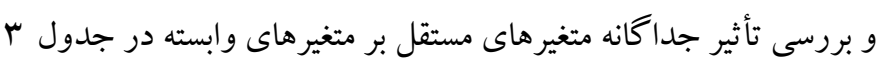
نتايج آزمونهاى اثرات بين آزمودنى ارائه شده است.

\begin{tabular}{|c|c|c|c|c|}
\hline \multicolumn{5}{|c|}{ در كروههاى آزمايش و كواه } \\
\hline معنادارى & F & آزادى درجه & مجذع سور & متغير \\
\hline$\cdot / \cdots 1$ & rVG/99 & 1 & YVISD/YA & رضامندى زوجيت \\
\hline 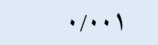 & r৭৭/.১ & 1 & $r|F| / G F$ & مهارت هاى ارتباطى \\
\hline
\end{tabular}




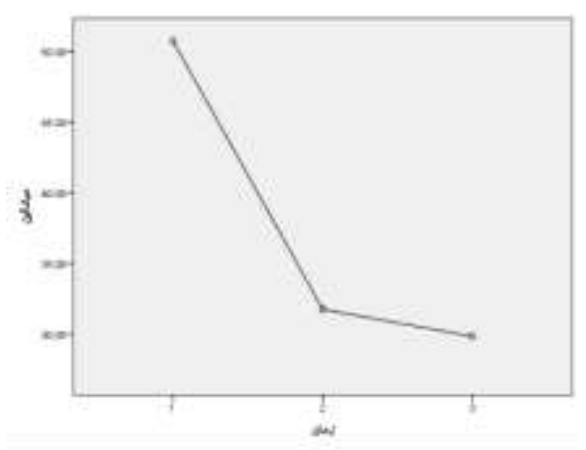

نمودار r: نمودار ميانغين مهارت ارتباطى كروه آزمايش در سه مرحله

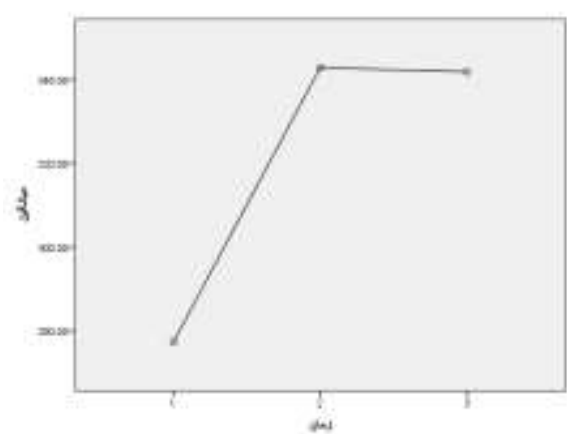

نمودار ا: نمودار ميانكين رضامندى زوجيت كروه آزمايش در سه مرحله
اسـت كه با بـزوهش حاضـر هماهنگك و همسو است. تفرشى و همكاران

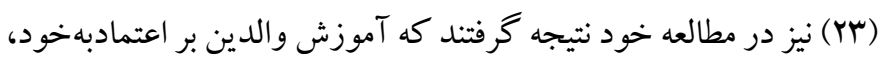
مهارت هاى خوديارى، ارتباطى و اجتماعى كود كك تأثير مثبت دارد كه با نيا نتايج يزوهش حاضر همسو است.

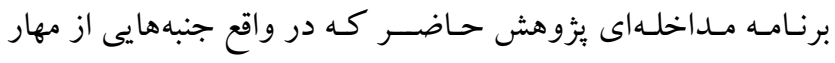

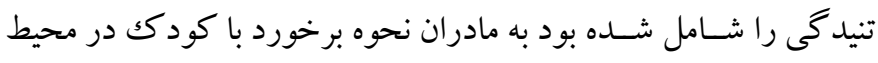

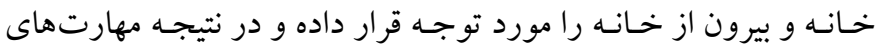

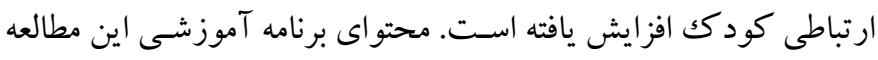

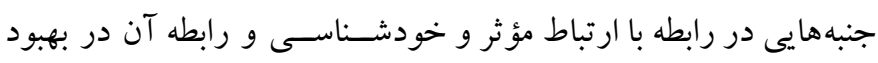

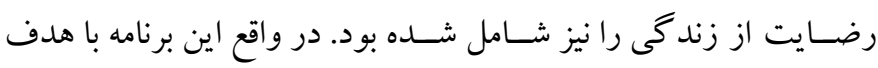

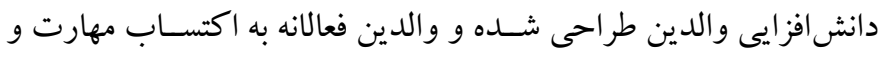
تغيير رفتار كودك تشويق شده بودند. لازم به ذكر است كه يافته هاى اين مطالعه با بزوهش حسين خانز اده و

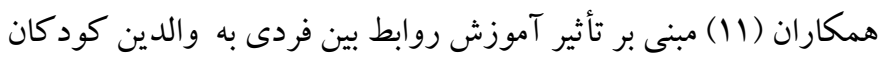
اوتيسم بر كاهش تنيدگى والدگرى و افسردگى همسو است. در همين

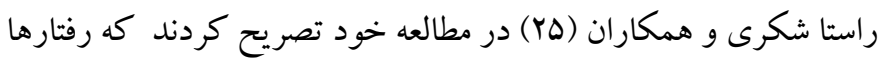
و حر كات كليشهاى كود كك اوتيسم كه مداوم در طى روز تكرار مى شود

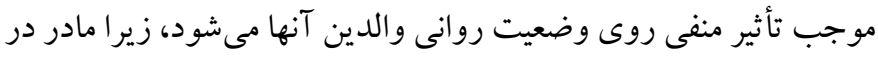

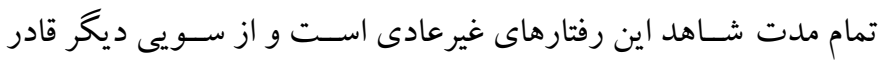
نيستـ اين رفتارها را كاهش داده و يا از بين ببرد؛ در نتيجه احساس عدم

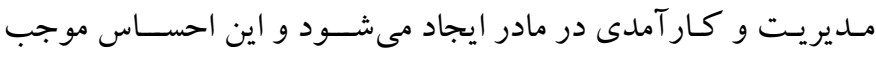

\section{بحث و نتيجه}

يزوهش حاضـر با هدف بررسـى تأثير آموزش تعاملات درون بحانواده به

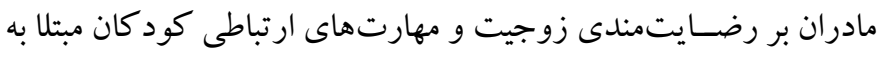

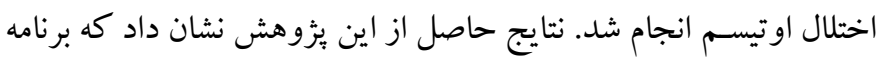

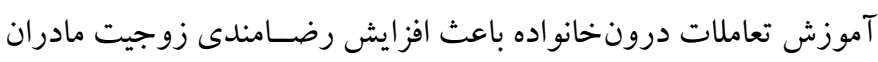

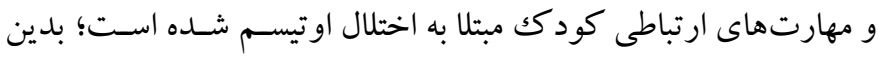

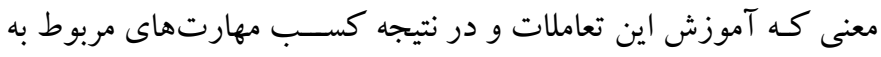

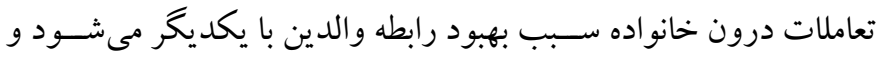
همين طور رضـايـتمنـدى زوجيت رادر آنها افزايش مىدهد. اين يافته

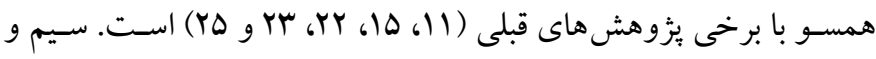

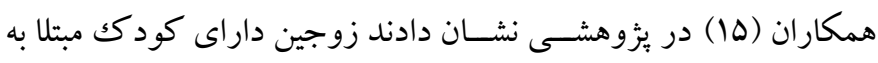
اختلالات طيف اوتيسـم در مقايسـه با زوجين داراى كودكك بهنجار از رضـايت برخوردار هسـتند. آنها همجنين تصــريح كردند كه عليرغم

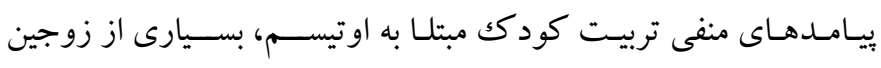

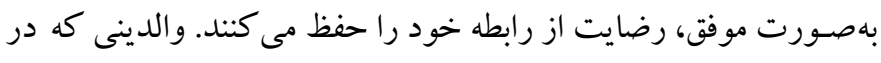

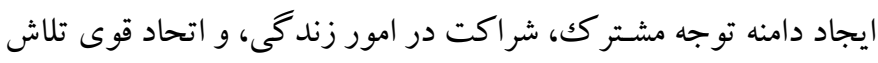
كردند، در نهايت رابطه منسـجم داشسته و با وجود تربيت كود كك مبتلا به

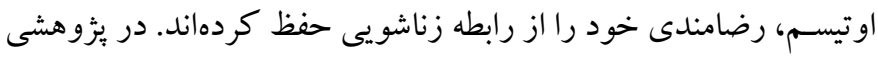

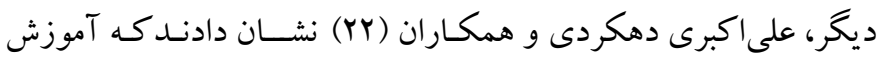

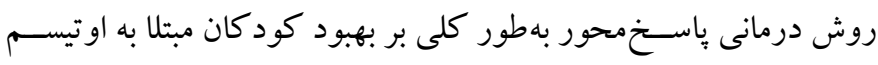

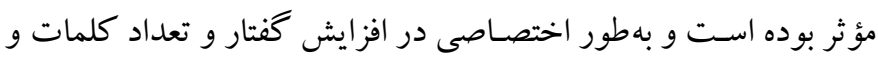

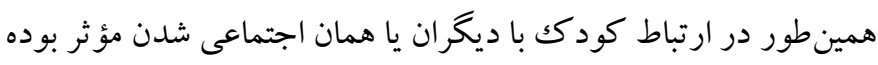


برخى از محدوديتهاى يُزوهش حاضـر مى توان به اين نكات اشاره

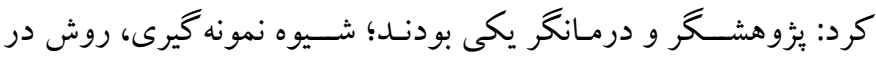

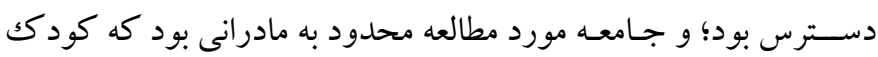
مبتلـا بـه اوتيســم خود را براى دريـافت خدمات درمانى به كلينيك احسيا

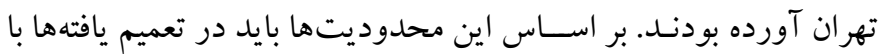
احتياط عمل كرد. همجنين بيشــنهاد مى شـــود اين مطالعه با حجم نمونه

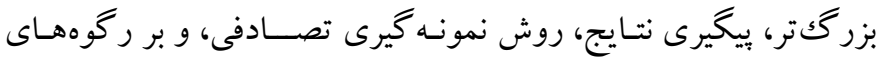
مختلف سنى و ذهنى انجام شود تا امكان تعميمدهى نتايج افزايش يابد. نئل تشكرو قدردانى: اين مقاله بر گرفته از بايانامه كارشناسى ارشد خانم صديقه

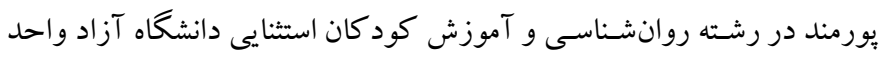

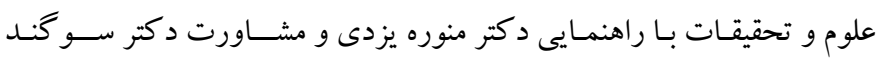

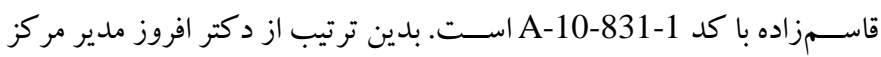

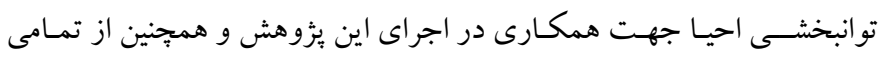
مادران شر كت كننده در اين مطالعه، تشكر و قدردانى مى شيود. تضاد و منافع: اين بثوهش بر ایى نويسند كان هيج گونه تضاد منافع ندارد.
افزايش افسـردگى، اضـطراب، آشـفتخى روانشـناختى، و تنش در مادر مىشود. نتايج اين بثروهش نشـان داد كه خودشـناسى، قدرت تصـميم گيرى،

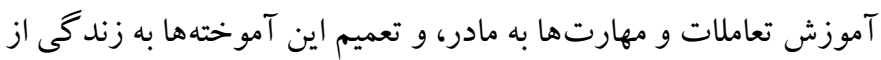
تنيـدكى مادر كم مى كند كه در واقع نياز مادران كود كان مبتلا به اختلال

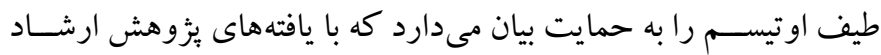

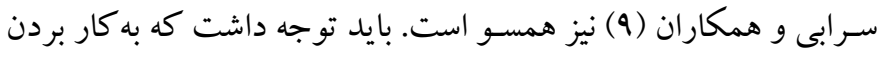

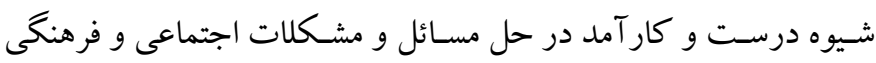

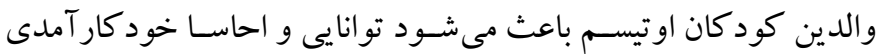
والدين بيشـتر شـود و به همان اندازه احسـاس روانى بهتر و مطلوبترى

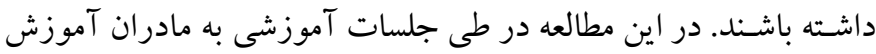

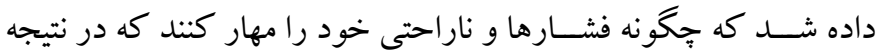

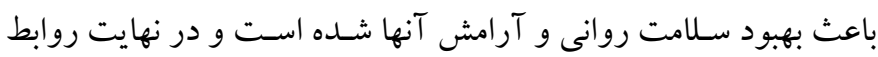
زناشويى والدين نيز بهتر و رضايتبخش تر شده بود. بدين ترتيب بيشنهاد

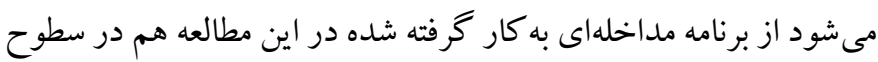
كلينكى و هم در سطوح مراكز آموزشى و توانبخشى استفاده شود. 


\section{References}

1. American Psychiatric Association. Diagnostic and statistical manual of mental disorders (DSM-5®).

Washington DC: American Psychiatric Pub; 2013. [Link]

2. Malek Pour M, Hadi S, Faramarzi S, Eshqi R, Keshavarz A. Comparison of the efficacy of family based, child based and family-child based interventions on the rate of ADHD's symptoms in children with ADHD. Family Counseling and Psychotherapy. 2015; 4(4): 653-672. [Persian]. [Link]

3. Kendall PC. Child psychopathology. Najjarian B, Davoodi I. (Persian translators). Fourth edition. Tehran: Roshd; 2016, p: 298. [Persian].

4. Baio J, Wiggins L, Christensen DL, Maenner MJ, Daniels J, Warren Z, et al. Prevalence Of autism spectrum disorder among children aged 8 years autism and developmental disabilities monitoring network, 11 sites, united states, 2014. MMWR Surveillance Summaries. 2018; 67(6): 1. [Link]

5. Beirami M, Hashemi Nosrat Abad T, Movahedi Y, Besharat R, Kohpeima S. Comparison of sleep quality components in autistic children's parents, normal and mentally retarded. Psychology of Exceptional Individuals. 2014; 4(13): 29-46. [Persian]. [Link]

6. Shiralinia K, Abdollahi Musavi H, Khojastemehr R. The effectiveness of group acceptance and commitment therapy (act)-based training on parenting stress and psychological flexibility in mothers of children with autism spectrum disorder. Psychology of Exceptional Individuals. 2018; 7(28): 21-44. [Persian]. [Link]

7. Estes A, Olson E, Sullivan K, Greenson J, Winter J, Dawson G, et al. Parenting-related stress and psychological distress in mothers of toddlers with autism spectrum disorders. Brain Dev. 2013; 35(2): 133-138. [Link]

8. Lilly J, Tungol JR. Effectiveness of mindfulness based psycho-educational program on parental stress of selected mothers of children with autism. Indian Journal of Positive Psychology. 2015; 6(1): 52-56. [Link]

9. Ershad Sarabi R, Hashemi Razini H, Abdollahi MH. Comparing parental stress, parenting styles, and social problem solving in mothers of children with autism spectrum disorder, ADHD, and typically developing children. Quarterly Journal of Child Mental Health. 2018; 4(4): 165-179. [Persian]. [Link]

10. Shojaee S. Challenges facing families with children with autism spectrum disorders. Quarterly Journal of
Child Mental Health. 2015; 2(1): 71-81. [Persian]. [Link]

11. Hossein Khanzadeh AA, Baghban Vahidi M, Nedaee $\mathrm{N}$. The impact of training mothers of autistic children for effective communication skills on family emotional conditions, adaptability and cohesion. Journal of Exceptional Children. 2017; 16(4): 39-50. [Persian]. [Link]

12. Kuhlthau K, Payakachat N, Delahaye J, Hurson J, Pyne JM, Kovacs E, et al. Quality of life for parents of children with autism spectrum disorders. Res Autism Spectr Disord. 2014; 8(10): 1339-1350. [Link]

13. Tripathi N. Parenting style and parents level of stress having children with autistic spectrum disorder (CWASD): a study based on Northern India. Neuropsychiatry. 2015; 5(1): 42-49. [Link]

14. Kwok SYCL, Leung CLK, Wong DFK. Marital satisfaction of Chinese mothers of children with autism and intellectual disabilities in Hong Kong. $\mathbf{J}$ Intellect Disabil Res. 2014; 58(12): 1156-1171. [Link]

15. Sim A, Cordier R, Vaz S, Falkmer T. Relationship satisfaction in couples raising a child with autism spectrum disorder: a systematic review of the literature. Res Autism Spectr Disord. 2016; 31: 30-52. [Link]

16. McCoy KP, George MRW, Cummings EM, Davies PT. Constructive and destructive marital conflict, parenting, and children's school and social adjustment. Soc Dev. 2013; 22(4): 641-662. [Link]

17. Robinson M, Neece CL. Marital satisfaction, parental stress, and child behavior problems among parents of young children with developmental delays J Ment Health Res Intellect Disabil. 2015; 8(1): 23-46. [Link]

18. Stipanicic A, Couture G, Rivest C, Rousseau M. Développement des modèles théoriques d'un programme destiné à des parents d'enfants présentant un trouble du spectre de l'autisme. J Dev Disabl. 2014; 20(3): 19-29. [Link]

19. Ahmadi A, Raeisi Z. The effect of acceptance and commitment therapy on distress tolerance in mothers of children with autism. Quarterly Journal of Child Mental Health. 2018; 5(3): 69-79. [Persian]. [Link]

20. Russell AJ, Murphy CM, Wilson E, Gillan N, Brown C, Robertson DM, et al. The mental health of individuals referred for assessment of autism spectrum disorder in adulthood: a clinic report. Autism. 2016; 20(5): 623-627. [Link]

21. Gorji R, Yektakhah S, Allameh M. General health and quality of life of mothers with autism child. 
Exceptional Education Journal. 2014; 1(123): 13-19. [Persian]. [Link]

22. Aliakbari Dehkordi M, Alipor A, Chimeh N, Mohtashami T. The effectiveness of parent-based pivotal response treatment on improvement of children with autism. Journal of Exceptional Children. 2012; 12(1): 5-16. [Persian]. [Link]

23. Fami Tafreshi F, Mohammadi MR, Sharifi Saki S, Ahmadi H, Karimi R, Aakhte M. Effectiveness of training applied behavior analysis to parents on increasing self-help of children with autism. Quarterly Journal of Child Mental Health. 2016; 3(1): 9-18. [Persian]. [Link]

24. Peters LC, Thompson RH. How teaching perspective taking to individuals with autism spectrum disorders affects social skills: findings from research and suggestions for practitioners. Behav Anal Pract. 2018; 11(4): 467-478. [Link]

25. Shokri S, Khanjani Z, Hashemi T. Prediction parents stress and psychological distress mothers on basis behavioral problems and adaptive functions primary school children with developmental delays. Quarterly Journal of Child Mental Health. 2016; 3(1): 95-108. [Persian]. [Link]

26. Ehlerz S, Gillberg C, Wing L. Screening questionnaire for Asperger syndrome and other high functioning autism spectrum disorders in school age children. J Autism Dev Disord. 1999; 29(2): 129141. [Link]

27. Strain PS, Hoyson M. The need for longitudinal, intensive social skill intervention: leap follow-up outcomes for children with autism. Topics Early Child Spec Educ. 2000; 20(2): 116-122. [Link]

28. Tincani M. Comparing the picture exchange communication system and sign language training for children with autism. Focus Autism Other Dev Disabl. 2004; 19(3): 152-163. [Link]

29. Dillenburger K, Keenan M. None of the As in ABA stand for autism: dispelling the myths. J Intellect Dev Disabil. 2009; 34(2): 193-195. [Link]

30. Gilliam J. Gilliam autism diagnostic exam guide. Ahmadi SJ, Safari T, Hemmatian M, Khalili Z. (Persian Translator). Center for education and rehabilitation of children with autism, Isfahan unit; 2009. [Persian].

31. Ebrahim Pour M, Afrooz GA, Pakdaman M, Davaei M. Developing and normalization of Afrooz effortcentered thinking and result centered thinking scale (AERS). Journal of Psychological Researches. 2013; 5(17): 30-41. [Persian]. [Link]

32. Beck A. Cognitive therapy and the emotional disorders. Oxford, England: International Universities Press; 1976. [Link] 